\title{
Prediction of the amount of methane produced by ruminants
}

\author{
By K. L. BLAXTER* AND J. L. CLAPPERTON \\ Hannah Dairy Research Institute, Ayr \\ (Received 23 March 1965-Accepted 3 August 1965)
}

Metabolizable energy is defined as the heat of combustion of a feed less the heat of combustion of the faeces, urine and gases which are produced when it is eaten. The losses of energy in faeces and urine can be determined easily in sheep and cattle kept in metabolism cages, but to determine the energy they lose as combustible gas, that is as methane, involves quantitative measurement of the gaseous exchange and the use of much more complex and expensive equipment. Understandably, several attempts have been made to predict the losses of energy as methane by cattle and sheep from knowledge of the amount and type of the food they ingest (Kriss, 1930; Bratzler \& Forbes, 1940; Swift, Bratzler, James, Tillman \& Meek, I948; Axelsson, I949). During the course of calorimetric experiments at this Institute many thousands of determinations of methane production by sheep and cattle during $24 \mathrm{~h}$ periods have been made. These observations have been used to extend an earlier analysis of the relation between methane production and the type and amount of the diet (Blaxter, 196r).

\section{METHODS}

Methane production was determined using closed-circuit respiration equipment (Wainman \& Blaxter, $195^{8} a, b$ ) in which the $\mathrm{CO}_{2}$ and $\mathrm{H}_{2} \mathrm{O}$ produced were absorbed continuously, the $\mathrm{O}_{2}$ consumed replaced continuously and the $\mathrm{CH}_{4}$ produced allowed to accumulate. From the volume of the chamber, the estimated volume of the animal, the barometric pressure, and the air temperature and humidity, the total volume of gas in the chamber at s.t.p. was calculated at the beginning and end of each day. $\mathrm{CH}_{4}$ concentration was determined in samples of gas taken at these times and $\mathrm{CH}_{4}$ production estimated as the difference between the final and initial volumes of $\mathrm{CH}_{4}$ at s.t.p. The calorific value of $\mathrm{I} 1 . \mathrm{CH}_{4}$ was taken to be $9 \cdot 44 \mathrm{kcal}$ throughout. In May 1964 this factor was changed, as the result of a recommendation by Professor Brouwer, to $9.45 \mathrm{kcal}$ (see Brouwer, 1965).

Gas analysis for $\mathrm{CH}_{4}$ until 1959 was by the Haldane method, in which the gas sample was burned in a gas pipette, and the total contraction in volume and the $\mathrm{CO}_{2}$ production were determined. After ${ }_{1959}, \mathrm{CH}_{4}$ was determined in gas samples, after removal of water vapour and of $\mathrm{CO}_{2}$, by burning the $\mathrm{CH}_{4}$ and measuring by thermal conductivity methods the amount of $\mathrm{CO}_{2}$ formed. The instrument used (Cambridge Instrument Company) was calibrated each day using standard $\mathrm{CH}_{4}$-free and $\mathrm{CH}_{4}$-containing gas mixtures, stored in cylinders.

Hydrogen, which on rare occasions arises in metabolic experiments with ruminants

* Present address : Rowett Research Institute, Bucksburn, Aberdeen. 
(Pilgrim, I948), was not determined routinely. When its presence was thought possible, that is when diets very high in starch content were given, during alimentation, or when an unexpectedly high $\mathrm{CH}_{4}$ production was noted, gas samples were analysed for $\mathrm{H}_{2}$ using the Haldane procedure. $\mathrm{H}_{2}$ was detected in two experiments only and then not on every day of the experiment, nor necessarily in parallel experiments in which other animals were given the same diet. The diets in these two experiments were flaked maize and sugar-beet pulp.

\section{Table I. Experiments included in the analysis}

\begin{tabular}{|c|c|c|c|}
\hline Species & $\begin{array}{l}\text { No. of } \\
\text { diets* }\end{array}$ & $\begin{array}{l}\text { No. of } \\
\text { experi- } \\
\text { ments }\end{array}$ & Reference \\
\hline Sheep & 2 & 12 & Blaxter \& Graham (1955) \\
\hline Sheep & 3 & 18 & Blaxter \& Graham (1956) \\
\hline Sheep & 3 & $3^{6}$ & $\begin{array}{l}\text { K. L. Blaxter \& N. McC. Graham (r957) (effects of grinding and } \\
\text { pelleting hay, unpublished) }\end{array}$ \\
\hline Sheep & $\mathbf{I}$ & 6 & Graham, Wainman, Blaxter \& Armstrong (1959) \\
\hline Sheep & 6 & 64 & A. K. Martin (1960) (diets containing groundnut cake, unpublished) \\
\hline Cattle & $\mathbf{I}$ & 12 & Blaxter \& Wainman $(\mathrm{I} 96 \mathrm{r} b)$ \\
\hline $\begin{array}{l}\text { Sheep and } \\
\text { cattle }\end{array}$ & $\mathbf{I}$ & 33 & Blaxter \& Wainman (1961 $a$ ) \\
\hline Sheep & 3 & 12 & Blaxter \& Wilson (1963) \\
\hline Sheep & I & I I & $\begin{array}{l}\text { J. L. Clapperton (1963) (nutritive value of sugar-beet pulp, unpub- } \\
\text { lished) }\end{array}$ \\
\hline Cattle & I & 20 & $\begin{array}{l}\text { K. L. Blaxter \& F. W. Wainman ( } 1963) \text { (effects of wind and rain, } \\
\text { unpublished) }\end{array}$ \\
\hline Sheep & I & 8 & Clapperton (1964a) \\
\hline Sheep & I & 10 & Clapperton (1964b) \\
\hline Cattle & 3 & 32 & Blaxter \& Wainman (1964a). \\
\hline $\begin{array}{l}\text { Sheep and } \\
\text { cattle }\end{array}$ & 6 & 72 & Blaxter \& Wainman $(1964 b)$ \\
\hline Sheep & 12 & 136 & Armstrong (1964) \\
\hline Sheep & 6 & 37 & J. L. Clapperton (1964) (nutritive value of silages, unpublished) \\
\hline Sheep & $\mathbf{I}$ & 9 & Bateman \& Blaxter (1964) \\
\hline Sheep & $\mathbf{I}$ & 30 & $\begin{array}{l}\text { K. L. Blaxter, J. L. Clapperton \& F. W. Wainman (1964) (meta- } \\
\text { bolism of different breeds of sheep, unpublished) }\end{array}$ \\
\hline Cattle & $\mathbf{I}$ & 54 & $\begin{array}{l}\text { K. L. Blaxter, J. L. Clapperton \& F. W. Wainman (1964) (effects of } \\
\text { age on feed utilization, unpublished) }\end{array}$ \\
\hline Sheep & $\mathbf{I}$ & 3 & Vercoe \& Blaxter (1965) \\
\hline Total & 55 & $6 I_{5}$ & \\
\hline
\end{tabular}

* With some of these diets one level of feeding only was used so that it was impossible to calculate the regression of $\mathrm{CH}_{4}$ production on level of feeding.

$\dagger$ An experiment consisted of a continued sojourn of an animal in a respiration chamber. Most of them were of $4-5$ days' duration but some were for several weeks.

The routine in most of the experiments was to confine the animal in the respiration apparatus for 4-5 consecutive days, during which time it received a constant amount of food each day. $\mathrm{CH}_{4}$ production was determined daily. The results of many of these experiments have been published and Table I lists the investigations included in the analysis. Experiments in which steam-volatile acids or other compounds were infused into the gut through fistulas were excluded. The number of daily determinations analysed was over 2500 . 
RESULTS

Analytical accuracy. Analysis of a standard gas mixture containing $4.0 \% \mathrm{CH}_{4}$ by the Haldane method resulted in a standard deviation of $\pm 0.05 \%$ or a coefficient of variation of $\pm \mathrm{x} \cdot 2 \%$. Daily analyses ( 166 ) over many weeks of a standard gas mixture using the automatic analyser resulted in a slightly higher standard deviation of $\pm 0.08 \%$, corresponding to a coefficient of variation of $\pm \mathrm{I} \cdot 7 \%$. The error attached to a single determination of $\mathrm{CH}_{4}$ production involving two analyses is thus about $\pm \mathrm{I} \cdot 7- \pm 2.4 \%$, if no account is taken of inaccuracies in measuring the temperature and pressure in the apparatus. It is unlikely that these would ever exceed $\pm I^{\circ}$ or $\pm \mathrm{I} \mathrm{mm} \mathrm{Hg}$; that is, errors due to these causes would be maximally \pm 0.4 and $\pm 0 . \mathrm{I} \%$ respectively. The total instrumental and analytical error involved in a single $24 \mathrm{~h}$ determination of $\mathrm{CH}_{4}$ was thus less than $\pm 3 \%$ of the amount determined.

Table 2. Day-to-day variation in $\mathrm{CH}_{4}$ production by sheep and cattle irrespective of type of food*

\begin{tabular}{|c|c|c|c|c|c|}
\hline $\begin{array}{c}\text { Range of } \mathrm{CH}_{4} \\
\text { production } \\
(\mathrm{l} . / 24 \mathrm{~b})\end{array}$ & $\begin{array}{c}\text { Mean } \mathrm{CH}_{4} \\
\text { production } \\
\quad(\mathrm{l} / \mathrm{24} \mathrm{h})\end{array}$ & $\begin{array}{c}\text { No. of } \\
\text { experiments }\end{array}$ & $\begin{array}{c}\text { Standard } \\
\text { deviation } \\
\text { (1./day) }\end{array}$ & $\begin{array}{l}\text { Degrees of } \\
\text { freedom }\end{array}$ & $\begin{array}{c}\text { Coefficient } \\
\text { of variation } \\
(\%)\end{array}$ \\
\hline \multicolumn{6}{|c|}{ Sheep } \\
\hline $10-20$ & 16.4 & 17 & $\pm I \cdot 59$ & 51 & $\pm 9 \cdot 7$ \\
\hline $20-30$ & $23 \cdot 7$ & 68 & $\pm I \cdot 95$ & 199 & \pm 8.2 \\
\hline $30-40$ & 35.9 & 44 & $\pm 2 \cdot 26$ & 129 & $\pm 6 \cdot 3$ \\
\hline $40-50$ & $42: 4$ & 31 & $\pm 2 \cdot 73$ & 92 & $\pm 6 \cdot 4$ \\
\hline Mean & $29^{\circ} 9$ & 160 & $\pm 2 \cdot 15$ & 471 & $\pm 7 \cdot 2$ \\
\hline $\begin{array}{l}\text { Flaked maize } \\
\text { alone }\end{array}$ & $23 \cdot 0$ & 9 & $\pm 2 \cdot 84$ & 27 & $\pm 12 \cdot 3$ \\
\hline \multicolumn{6}{|c|}{ Cattle } \\
\hline $50-100$ & $73 \cdot 4$ & 15 & \pm 7.72 & 45 & \pm 10.5 \\
\hline $100-15^{\circ}$ & $124: 6$ & 24 & \pm 5.65 & 46 & \pm 4.5 \\
\hline $150-200$ & 169.7 & 33 & $\pm 13 \cdot 32$ & 99 & \pm 7.9 \\
\hline $200-300$ & $248 \cdot 5$ & 15 & \pm 12.75 & 45 & $\pm 5 \cdot I$ \\
\hline Mean & I $54^{\circ} 2$ & 87 & $\pm I I \cdot I I$ & 235 & $\pm 7 \cdot 2$ \\
\hline
\end{tabular}

* As discussed below, small systematic effects due to the day of confinement in the chamber have been ignored in this table.

The day-to-day variation in $\mathrm{CH}_{4}$ production in individual sheep. The results of 210 experiments with sheep and 129 experiments with cattle, involving $98924 \mathrm{~h}$ determinations of $\mathrm{CH}_{4}$ production, were analysed to find the day-to-day variation in $\mathrm{CH}_{4}$ production of an individual animal when constant feed was given. The results are shown in Table 2. Analyses of variance showed that $\mathrm{CH}_{4}$ production was $2 \cdot 2 \%$ lower on the Ist day of confinement than on subsequent days, this effect being statistically significant $(P<0.05)$. The reason for this small effect may lie in the high solubility of $\mathrm{CH}_{4}$ in body fat and the fact that the concentration of $\mathrm{CH}_{4}$ in chamber air was higher than in the rooms in which the animals were confined before being admitted to the chamber. Ignoring this small systematic effect, the day-to-day variation in $\mathrm{CH}_{4}$ production by sheep and cattle was $\pm 7 \cdot 2 \%$ of the amount determined. This value is greater than the instrumental error of $\pm 3 \%$. With both cattle and sheep the 
absolute error attached to a single estimate of $\mathrm{CH}_{4}$ production increased with increasing $\mathrm{CH}_{4}$ production, whereas the relative error declined. High relative errors were encountered when diets consisting entirely of flaked maize were given to sheep (Table 2). The error attached to mean values for the $\mathrm{CH}_{4}$ produced by an animal given constant feed, calculated over 4 days, can be taken to be $\pm 3.6 \%$ of the amount present. This includes instrumental error.

Variation in the $\mathrm{CH}_{4}$ production by the same animal over long periods of time. In twenty-one investigations with sheep and in five investigations with cattle, constant diets were given for periods ranging from 26 to 46 days, and $\mathrm{CH}_{4}$ production was determined. $\mathrm{CH}_{4}$ production was recorded over a total period of $94 \mathrm{I}$ days involving 448 determinations of the $24 \mathrm{~h}$ production. These experiments were analysed separately from the $4^{-}$or 5 -day experiments recorded above by determining the regression of $\mathrm{CH}_{4}$ production on time, and the residual standard deviation. None of the five steers showed a change in $\mathrm{CH}_{4}$ production with time, the mean daily decline in $\mathrm{CH}_{4}$ production being $0.16 \pm 0.19 \mathrm{l}$. The residual standard deviation was $\pm 7 \cdot 1 \mathrm{l}$./day, that is lower than that noted in 4-day trials. With sheep, however, eight of the twenty-one regression coefficients were significantly $(P<0.05)$ different from zero, all of them being positive. One of the regression coefficients was greater than I $\%$ of the mean daily $\mathrm{CH}_{4}$ production, all others being less. When results for all the sheep were combined there was no significant trend in $\mathbf{C H}_{\mathbf{4}}$ production and the residual standard deviation was $\pm I \cdot 961 . / 24 \mathrm{~h}$ or $\pm 6 \cdot \mathrm{I} \%$ of the mean amount found. This last error is also slightly lower than that noted in 4- or 5-day trials. The reason for the slight increases in $\mathrm{CH}_{4}$ production by some sheep on constant diets with time may reflect a slow adjustment of the flora of their alimentary tracts to their diet. In each of these long-term experiments, however, the animals had been accustomed to the diets for at least 2 weeks before measurement began.

Variation between the $\mathrm{CH}_{4}$ production of different animals given the same feed. In twenty-three investigations two or more sheep were offered the same amount of the same diet and $\mathrm{CH}_{4}$ was measured for 4 or 5 days. Small refusals of feed sometimes occurred, however, so that intakes were not precisely the same for each animal. For this reason $\mathrm{CH}_{4}$ productions were expressed as $\mathrm{kcal} \mathrm{CH}_{4} / \mathrm{roo} \mathrm{kcal} \mathrm{feed} \mathrm{ingested.} \mathrm{These}$ observations permit calculation of whether sheep differ one from another in the amount of $\mathrm{CH}_{4}$ they produce.

An analysis of variance of these results gave the values shown in Table 3. Differences between the amounts of $\mathrm{CH}_{4}$ produced by sheep given the same amount of the same feed were highly significant statistically. Part of these differences could be due to size or breed of sheep. In a series of thirty experiments each lasting 5 days five sheep of six different breeds differing markedly in size were all given the same feed in amounts which were constant per kg body-weight raised to the power 0.73 . An analysis of variance of the results is also shown in Table 3. Differences in $\mathrm{CH}_{4}$ production between individuals were still apparent but these were unrelated to breed.

From the analyses of variance in Table 3 it can be computed that the animalto-animal variation in $\mathrm{CH}_{4}$ production was \pm 0.56 and $\pm 0.59 \mathrm{kcal} / \mathrm{roo} \mathrm{kcal}$ feed 
consumed in the two series. These values are $\pm 7 \cdot 2$ and $\pm 8 \cdot I \%$ of their respective means.

Effect of amount and type of diet on $\mathrm{CH}_{4}$ production by sheep. In all investigations to determine the nutritive value of diets as sources of energy the practice in this laboratory is to give the diet in two or more amounts to each of three or four sheep, and to measure $\mathrm{CH}_{4}$ production for 4 or 5 days on each occasion. In this way, fortyeight diets have been investigated, involving $39 \mathrm{I} 4^{-}$or 5 -day measurements of $\mathrm{CH}_{4}$ production. As the amount of feed given to a ruminant is increased, $\mathrm{CH}_{4}$ production also increases. To examine the relation between the amount of feed consumed and

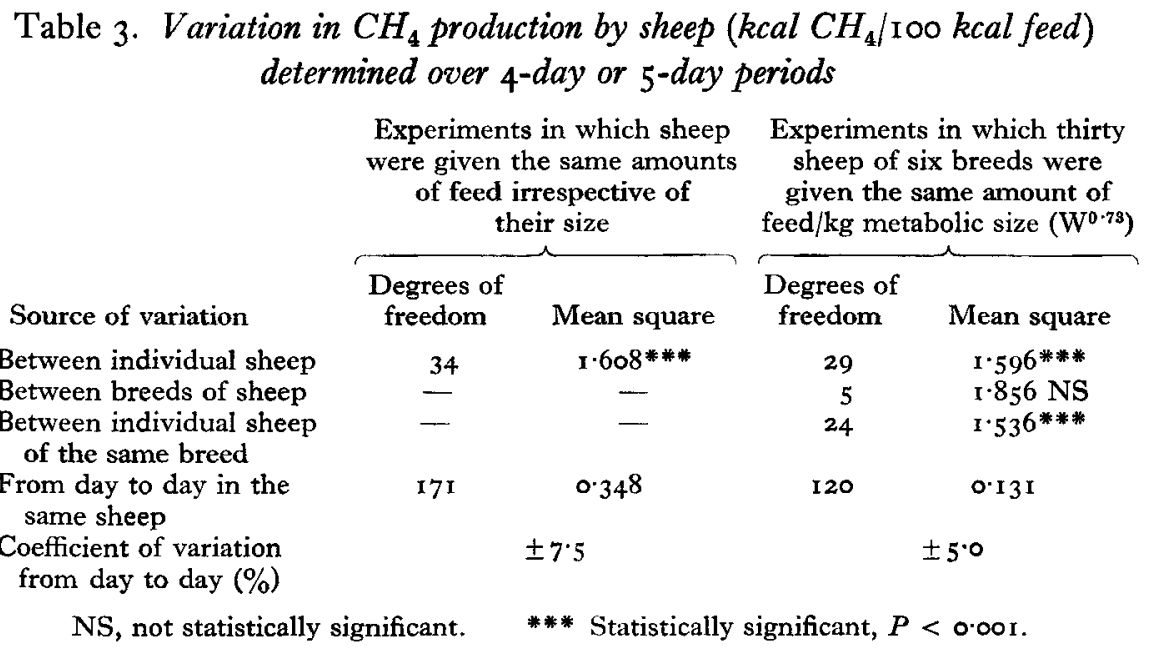

$\mathrm{CH}_{4}$ production, the relation between the percentage of the dietary energy lost as $\mathrm{CH}_{4}$ and the feeding level was analysed. Feeding level $(L)$ is defined as the amount of feed consumed divided by the amount required when energy retention is zero, that is the amount required at maintenance. Linear regression was used according to the equation

$$
\mathrm{CH}_{4}(\mathrm{kcal} / \mathrm{roO} \mathrm{kcal} \text { feed })=a \pm b L,
$$

$b$ being the change in methane production per unit increase in feeding level and the $a$ intercept of the equation.

In all forty-eight trials the regression of $\mathrm{CH}_{4}$ production on feeding level was negative. There is no doubt, therefore, that though the absolute amount of $\mathrm{CH}_{4}$ produced increases with increased feeding level the increase is at an ever-decreasing rate. $\mathrm{CH}_{4}$ production/unit feed consumed has also been found to fall with feeding level in experiments with cows by Coppock, Flatt, Moore \& Stewart (ig65).

The mean $\mathrm{CH}_{4}$ production expressed as a percentage of dietary energy at the maintenance level-that is, when the feeding level in the equation above is $\mathrm{I} \cdot 0$ - was $8.07 \mathrm{kcal} \mathrm{CH}_{4} / 100 \mathrm{kcal}$ feed with a range from 6.2 to $10.8 \mathrm{kcal} \mathrm{CH}_{4} / 100 \mathrm{kcal}$, the lowest value being for a pelleted meadow-fescue grass and the highest for sugar-beet pulp given as sole feed.

The apparent digestibility of dietary energy was determined in all the trials, and 
also decreased with increasing feed intake. Apparent digestibility at the maintenance level of nutrition was determined by regression methods for each of the forty-eight diets, the range being from $54^{.8}$ for a poor hay to 87.2 for sugar-beet pulp given as the sole feed. Fig. I shows $\mathrm{CH}_{4}$ production/ $100 \mathrm{kcal}$ feed at maintenance plotted against apparent digestibility at the maintenance level. The diets used were separated into three classes: roughages, including dried grasses, hays and silages (twenty-nine); mixed diets, for the most part containing some hay (eleven); and diets composed of pelleted or milled materials (eight). These three classes are shown in Fig. I, and Table 4 summarizes the regression equations for each class. No attempt was made to weight the observations according to number of replications in arriving at these regressions.

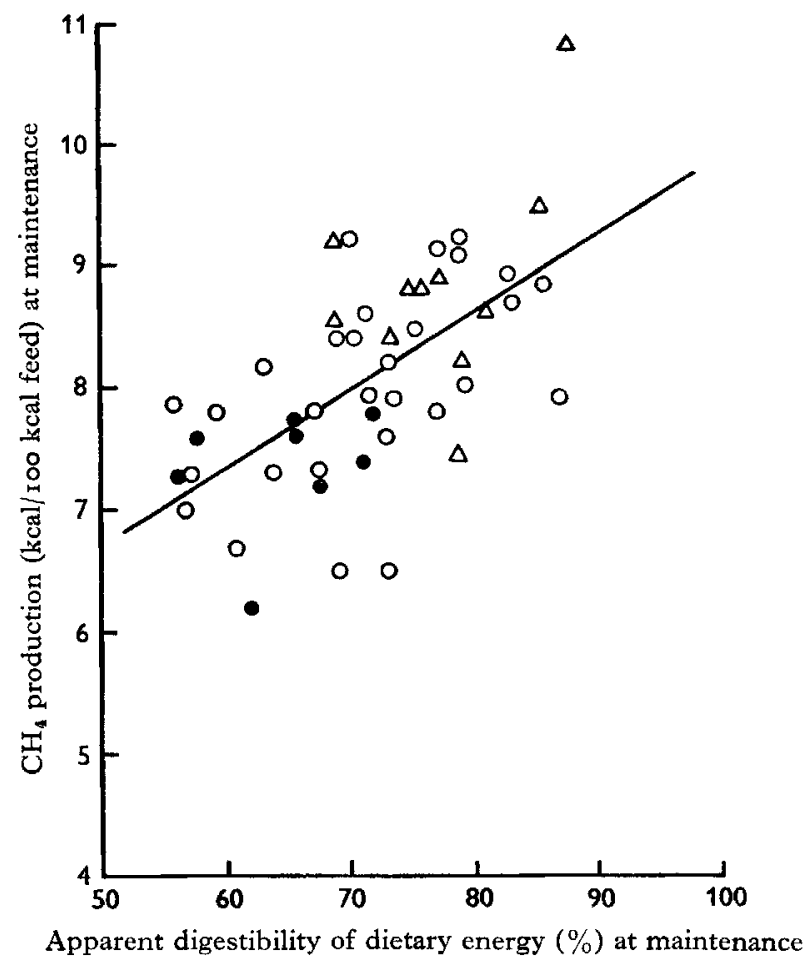

Fig. I. Relation in sheep and cattle between $\mathrm{CH}_{4}$ production at maintenance and the apparent digestibility, at maintenance, of dietary energy in : $\circ$, roughages; $\bullet$, pelleted or milled feeds; $\Delta$, mixed diets.

With each class of diet, $\mathrm{CH}_{4}$ production at the maintenance level $\left(C_{m}\right)$ increased with increased apparent digestibility of the diet (D). The equation for the twenty-nine roughages (Table 4) was not very different from that calculated by Blaxter (196I) from results for twelve of the diets included in this analysis $\left(C_{m}=4 \cdot 28+0.059 D\right.$, with a residual standard deviation of \pm 0.47$)$. The equation for pelleted diets is that calculated earlier, since no new observations with pellets have been made since 1961).

Analysis of covariance showed that the differences between these regressions were 
not statistically significant. Adjusted means obtained by using a common regression coefficient did not differ from class to class of feed. For practical purposes, the equation developed for all diets can therefore be used to predict $\mathrm{CH}_{4}$ production. The error attached to predicted values is approximately $\pm 0.7 \mathrm{kcal} / \mathrm{I} 00 \mathrm{kcal}$ feed or $\pm 8 \%$ of the mean amount of methane produced.

Table 4. Regressions of $\mathrm{CH}_{4}$ production (kcal/10o kcal feed) on apparent digestibility of dietary energy $(\%)$, both determined at the maintenance level of feeding for different classes of diet

\begin{tabular}{lcccc}
\multicolumn{1}{c}{ Diet class } & $\begin{array}{c}\text { No. of } \\
\text { diets }\end{array}$ & Regression equation* & $\begin{array}{c}\text { Residual } \\
\text { standard } \\
\text { deviation }\end{array}$ & $\begin{array}{c}\text { Statistical } \\
\text { significance } \\
\text { of regression }\end{array}$ \\
Roughages & 29 & $C_{m}=4.67+0.047 D$ & \pm 0.68 & $P<0.01$ \\
Mixed diets & II & $C_{m}=3.03+0.074 D$ & \pm 0.84 & $P<0.01$ \\
Pelleted diets & 8 & $C_{m}=6.05+0.020 D$ & \pm 0.53 & NS \\
All diets & 48 & $C_{m}=3.67+0.062 D$ & \pm 0.71 & $P<0.001$
\end{tabular}

NS, not statistically significant.

* $\mathrm{CH}_{4}$ at maintenance $(\mathrm{kcal} / \mathrm{roo} \mathrm{kcal})=C_{m}$; apparent digestibility (kcal/100 kcal) $=D$.

Table 5. Regressions of the change in $\mathrm{CH}_{4}$ production on increasing feeding level by one multiple of maintenance ( $\mathrm{kcal} / \mathrm{I} 00 \mathrm{kcal}$ feed) on apparent digestibility of dietary energy $(\%)$ determined at the maintenance level of feeding

\begin{tabular}{lcccc}
\multicolumn{1}{c}{ Diet class } & $\begin{array}{c}\text { No. of } \\
\text { diets }\end{array}$ & Regression equation* & $\begin{array}{c}\text { Residual } \\
\text { standard } \\
\text { deviation }\end{array}$ & $\begin{array}{c}\text { Statistical } \\
\text { significance } \\
\text { of regression }\end{array}$ \\
Roughages & 29 & $b=0.028 D-1.03$ & \pm 0.34 & $P<0.01$ \\
Mixed diets & $1 \mathbf{I}$ & $b=0.054 D-2.26$ & \pm 0.89 & NS \\
Pelleted diets & 8 & $b=0.059 D-2.67$ & \pm 0.47 & NS \\
All diets & 48 & $b=0.050 D-2.37$ & \pm 0.65 & $P<0.00 \mathrm{I}$
\end{tabular}

NS, not statistically significant.

* Change in $\mathrm{CH}_{4}$ production on increasing feeding level by one multiple of maintenance (kcal/100 kcal diet $)=b$; apparent digestibility of dietary energy $(\%)$ at maintenance feeding level $=D$.

Table 5 summarizes the results of a similar regression analysis of the change in $\mathrm{CH}_{4}$ production when feeding level is increased on apparent digestibility at the maintenance level; these results calculated at various values for apparent digestibility have been used to plot Fig. 2. There were no differences between the regressions or adjusted means given in Table 5 , and the equation based on all values can be taken to be representative. This equation shows that with poor-quality feeds with a low apparent digestibility, an increase in feeding level has little effect on $\mathrm{CH}_{4}$ production when it is expressed as a percentage of intake. With high-quality feeds, however, increases in feeding level result in a depression in the amount of $\mathrm{CH}_{4}$ produced/roo kcal feed consumed. The two equations relating (a) $\mathrm{CH}_{4}$ production at the maintenance level and (b) the change in $\mathrm{CH}_{4}$ production with changes in feeding level to apparent digestibility can be combined to give

$$
\mathrm{CH}_{4}=1 \cdot 30+0.112 D-L(2 \cdot 37-0.050 D) \text {, }
$$

where $D=$ digestibility at the maintenance level of feeding and $L=$ level of feeding 


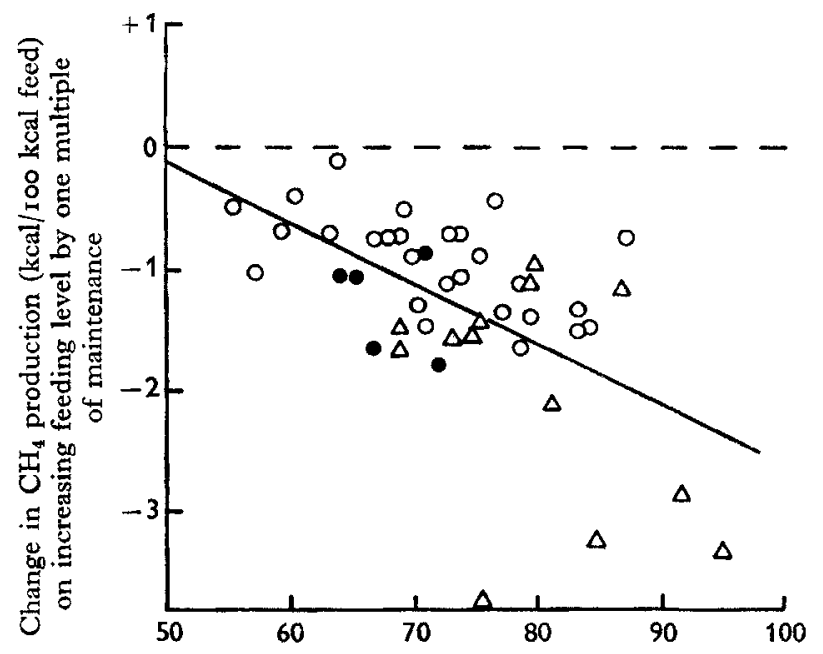

Apparent digestibility of dietary energy $(\%)$ at maintenance

Fig. 2. Relation in sheep and cattle between the change in $\mathrm{CH}_{4}$ production on increasing the level of feeding by one multiple of maintenance and the apparent digestibility of dietary energy in: $\odot$, roughages; $\bullet$, pelleted or milled feeds; $\Delta$, mixed diets.



Fig. 3. Estimated $\mathrm{CH}_{4}$ production by sheep and cattle receiving at different levels feeds of different apparent digestibilities. 
as a multiple of the maintenance level. Values obtained with this equation are given in Fig. 3 for three levels of feeding.

Cattle and sheep. When seven different diets were given to both sheep and cattle no significant differences between the two species were found in the amounts of $\mathrm{CH}_{4}$ produced at the maintenance level (Blaxter \& Wainman, 196r $a$, г964a).

\section{DISCUSSION}

$\mathrm{CH}_{4}$ is produced by the micro-organisms present in the digestive tracts of ruminants, notably in the rumen, but probably in the caecum also. The day-to-day variation in $\mathrm{CH}_{4}$ production noted here, which exceeds considerably the analytical error attached to a daily determination, could well arise from changes in the activity of these organisms, but it is more likely to be accounted for by the fact that the greater part of the $\mathrm{CH}_{4}$ excretion is by eructation (Joyce \& Blaxter, 1963 ; Hoernicke, Williams, Waldo \& Flatt, 1965), a process which is not continuous. The evidence for a sequential change in the $\mathrm{CH}_{4}$ production of some sheep when given constant amounts of a diet of constant composition over long periods suggests, however, that the number or activity of those micro-organisms which produce $\mathrm{CH}_{4}$ can change. Evidence that $\mathrm{CH}_{4}$ production in sheep, given either the same absolute amount of feed or the same amount of feed relative to their size, varies significantly from individual to individual also suggests that variations in the methanogenic flora of the rumen can occur. Even so, the extent of these variations is small when expressed as coefficients of variation, for the inter-animal variation and the day-to-day variation each amounts to about $\pm 8 \%$ of the amount produced.

There was no doubt that the amount of $\mathrm{CH}_{4}$ produced was influenced by the diet given. The results show that at the maintenance level of feeding the higher the apparent digestibility of a feed, the greater the $\mathrm{CH}_{4}$ production/100 kcal feed consumed, and that doubling feed intake depressed $\mathrm{CH}_{4}$ production more with the high-quality materials than with the low-quality ones. At the maintenance level of nutrition the $\mathrm{CH}_{4}$ loss was 6.7 and $9.3 \%$ of the energy ingested for feeds with an apparent digestibility of 50 and $90 \%$ respectively. In terms of the apparent digestible energy of feed, $\mathrm{CH}_{4}$ losses can be calculated to range from $\mathrm{r}_{3} .4 \%$ for feed with an apparent digestibility of $50 \%$ to $10.3 \%$ for feed with an apparent digestibility of $90 \%$.

The higher the apparent digestibility of a feed, however, the less of it is required to maintain an animal. An analysis of the effect of feed quality could equally have been based on comparisons made when equal amounts of dry matter were consumed each day; in these circumstances the change in $\mathrm{CH}_{4}$ production/kg increase in drymatter consumption could have been the subject of analysis.

The relation between the amount of dry feed, the apparent digestibility of its energy and $\mathrm{CH}_{4}$ production can, however, be computed from a knowledge of the energy requirements for maintenance (Blaxter, 1964). The results of such a computation are given in Fig. 4. It shows that when the apparent digestibility of feed is low the amount of $\mathrm{CH}_{4}$ produced, expressed as $\mathrm{kcal} / \mathrm{roO} \mathrm{kcal}$ feed, is virtually independent of the amount of feed, that with small absolute amounts of feed, production of $\mathrm{CH}_{4}$ rises with 
apparent digestibility and with large amounts it tends to fall. The reasons for these relationships probably lie in variations, with amount and type of diet, in the rates of flow of material from the rumen.

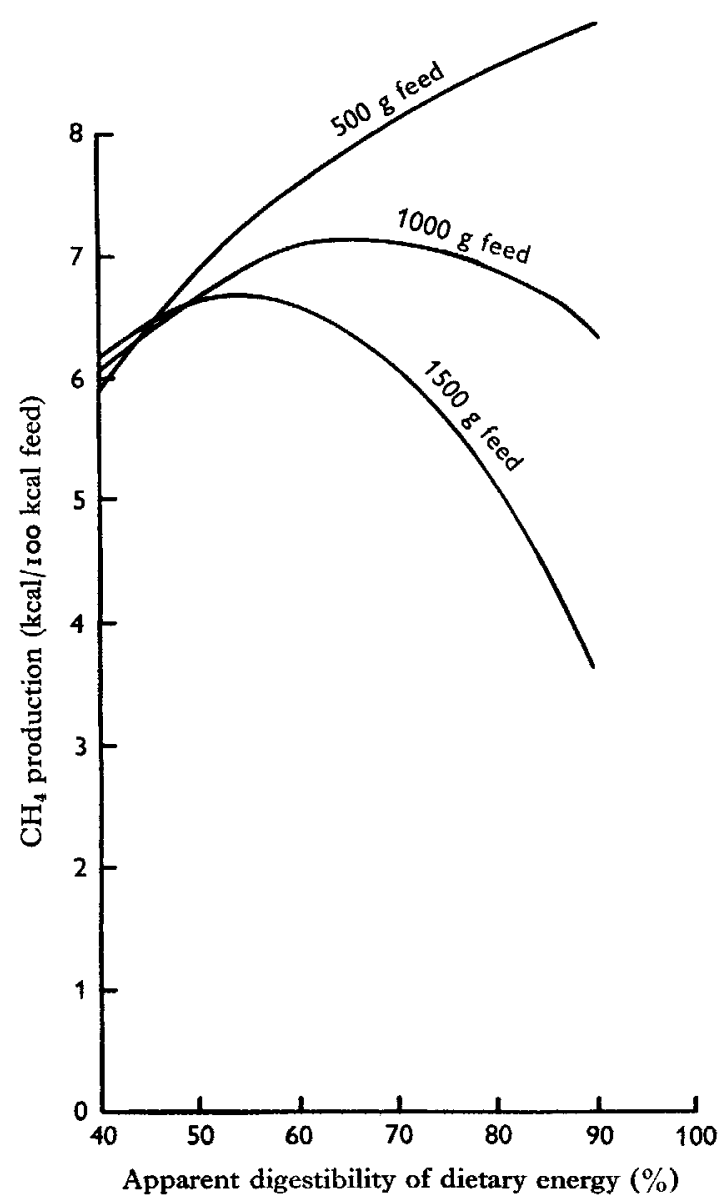

Fig. 4. Estimated $\mathrm{CH}_{4}$ production by sheep and cattle receiving constant amounts of feed of different apparent digestibilities.

Previous estimates of $\mathrm{CH}_{4}$ production by ruminants have been based on either the dry matter consumed (Kriss, I930; Axelsson, 1949) or on the total amount of digested carbohydrate supplied by the diet (Bratzler \& Forbes, 1940; Swift et al. 1948). The results obtained above suggest that the latter approach is open to error. Thus, since most of the diets given in our experiments varied little in their protein, ash and lipid contents, the amounts of apparently digested carbohydrate at any particular feeding level were much the same for feeds of high and of low digestibility. The $\mathrm{CH}_{4}$ production with these diets, however, was found to vary considerably.

The same criticism, that no attempt was made to take into account the type of diet, can be levied against those equations based on dry-matter intakes. In addition, there is evidence that the effect of nutritional level on $\mathrm{CH}_{4}$ production has not been wholly 
taken into account. Kriss (I930) showed, for example, that the $\mathrm{CH}_{4}$ production of cattle was linearly related to dry-matter consumption by the equation

$$
\mathrm{CH}_{4}(\mathrm{~g} / \text { day })=\mathrm{I} 8+22 \cdot 5 \mathrm{I} \text {, }
$$

where $I$ is the dry-matter intake $(\mathrm{kg} / \mathrm{day})$. On the assumption that the calorific value of the feeds used varied little from $4.4 \mathrm{kcal} / \mathrm{g}$, this equation is reduced to

$$
\mathrm{CH}_{4}(\mathrm{kcal} / \mathrm{I} 00 \mathrm{kcal} \text { feed })=6 \cdot 8+(243 / x) \text {, }
$$

where $x$ is the number of kcal feed ingested. This equation suggests a much greater constancy of $\mathrm{CH}_{4}$ production with amount of diet than we have found. Similarly Axelsson (1949) found that with cattle $\mathrm{CH}_{4}$ production could be predicted from the equation

$$
\mathrm{CH}_{4}(\mathrm{kcal} / \text { day })=-494+0.629 I-25 \cdot 0 I^{2},
$$

where $I$ is the dry-matter intake in $\mathrm{kg} /$ day. This equation can be reduced to

$$
\mathrm{CH}_{4}(\mathrm{kcal} / \mathrm{I} 00 \mathrm{kcal} \text { feed })=14.3-(49400 / x)-0.000129 \mathrm{r} x \text {, }
$$

where $x$ is the number of $\mathrm{kcal}$ of feed. This equation suggests that a maximal $\mathrm{CH}_{4}$ production of $9.2 \mathrm{kcal} / \mathrm{roo} \mathrm{kcal}$ feed occurs when the animal receives 44 Mcal feed $(4 \mathrm{~kg})$, and that it subsequently declines. The range of variation of $\mathrm{CH}_{4}$ production predicted by this equation is, however, smaller than we have found.

\section{SUMMARY}

I. The results of more than 2500 determinations of the $24 \mathrm{~h}$ production of methane by sheep and cattle, made incidentally to other experiments, were analysed statistically.

2. Expressed as coefficients of variation, analytical error was less than $\pm 3 \%$, dayto-day variation in the same animal $\pm 7 \%$ and between-animal variation (sheep) $\pm 7-8 \%$.

3. In each of forty-eight trials with different feeds, $\mathrm{CH}_{4}$ production expressed as $\mathrm{kcal} \mathrm{CH}_{4} / \mathrm{roo} \mathrm{kcal}$ feed fell as the level of feeding increased.

4. At the maintenance level of nutrition, $\mathrm{CH}_{4}$ production $\left(C_{m}, \mathrm{kcal} / \mathrm{roo} \mathrm{kcal}\right.$ feed) varied from 6.2 to 10.8 and was related to the apparent digestibility of the energy of the feed $(D)$ by the equation $C_{m}=3.67+0.062 D$. The regression was highly significant statistically and the residual standard deviation $\pm 0.7 \mathrm{I}$ or $\pm 8 \%$ of the mean amounts.

5. The change in $\mathrm{CH}_{4}$ production when feeding level was increased from maintenance to $2 \times$ maintenance $\left(b, \mathrm{kcal} \mathrm{CH}_{4} / \mathrm{I} 00 \mathrm{kcal}\right.$ feed per unit) was also related to the apparent digestibility $(D)$ of the energy of the feed by the equation, $b=0.050 D-2 \cdot 37$. This equation was also highly significant statistically.

6. The two equations show that as the apparent digestibility of feed increases, $\mathrm{CH}_{4}$ production, expressed as $\mathrm{kcal} / \mathrm{roo} \mathrm{kcal}$ feed, increases markedly at the maintenance level of feeding, but at feeding levels of $3 \times$ maintenance it falls. 


\section{REFERENCES}

Armstrong, D. G. (1964). F. agric. Sci., Camb., 62, 399.

Axelsson, J. (1949). K. LantbrHögsk. Annlr, 16, 404.

Bateman, J. V. \& Blaxter, K. L. (1964). F. agric. Sci., Camb., 63, 129.

Blaxter, K. L. (г96r). Publs Eur. Ass. Anim. Prod. no. 1o, p. 2 I.

Blaxter, K. L. (r964). Proc. Nutr. Soc. 23, 62.

Blaxter, K. L. \& Graham, N. McC. (1955). J. agric. Sci., Camb., 46, 293.

Blaxter, K. L. \& Graham, N. McC. (1956). F. agric. Sci., Camb., 47, 207.

Blaxter, K. L. \& Wainman, F. W. (1961 a). F. agric. Sci., Camb., 57, 419.

Blaxter, K. L. \& Wainman, F. W. (rg6r b). F. agric. Sci., Camb., 56, 8r.

Blaxter, K. L. \& Wainman, F. W. (r964a). F. agric. Sci., Camb., 63, 113.

Blaxter, K. L. \& Wainman, F. W. (1964b). F. agric. Sci., Camb., 62, 207.

Blaxter, K. L. \& Wilson, R. S. (1963). Anim. Prod. 5, 27.

Bratzler, J. W. \& Forbes, E. B. (1940). F. Nutr. 19, 6r г.

Brouwer, E. (1965). Publs Eur. Ass. Anim. Prod. no. I I, p. 441.

Clapperton, I. L. (1964a). Br. $\mathcal{F}$. Nutr. I8, 47.

Clapperton, J. L. (1964b). Br. F. Nutr. r8, 39.

Coppock, C. E., Flatt, W. P., Moore, L. A. \& Stewart, W. E. (1965). F. Dairy Sci. 47, 1330.

Graham, N. McC., Wainman, F. W., Blaxter, K. L. \& Armstrong, D. G. (1959). Y. agric. Sci., Camb., 52, I3.

Hoernicke, H., Williams, W. F., Waldo, D. R. \& Flatt, W. P. (1965). Publs Eur. Ass. Anim. Prod. no. II, p. 165 .

Joyce, J. P. \& Blaxter, K. L. (1963). Br. F. Nutr. 17, 523.

Kriss, M. (r930). Ұ. agric. Res. 40, 283.

Pilgrim, A. F. (1948). Aust. F. scient. Res. B, I, 130.

Swift, R. W., Bratzler, J. W., James, W. H., Tillman, A. D. \& Meek, D. C. (1948). J. Anim. Sci. 7, 475 .

Vercoe, J. E. \& Blaxter, K. L. (1965), Br. F. Nutr. I9, 523.

Wainman, F. W. \& Blaxter, K. L. (I958a). Publs Eur. Ass. Anim. Prod. no. 8, p. 80.

Wainman, F. W. \& Blaxter, K. L. (1958b). Publs Eur. Ass. Anim. Prod. no. 8, p. 85. 